TEME, г. XLIV, бр. 1, јануар - март 2020, стр. 209-229

Прегледни рад

Примљено: 31. 5. 2017.

https://doi.org/10.22190/TEME170531017I

Ревидирана верзија: 10. 2. 2020.

Одобрено за штампу: 20. 2. 2020.

\title{
BACKDOOR POLITICS: PERMITTING INFORMALITY \\ FOR FORMAL DEVELOPMENT \\ IN AFRICAN DEMOCRACIES
}

\author{
Aluko Opeyemi Idowu \\ University of Ilorin, Political Science Department, Nigeria \\ opealukoheavenprogress@gmail.com
}

\begin{abstract}
The backdoor politics is a general term behind the study of effective and responsible public policy from the perspective of informal political processes. The study analyses informal input determinants that affect responsible public politics. The methodology utilises data from the Afrobarometer database, assessing three countries in Africa, from the east, west and southern parts - Kenya, Nigeria and South Africa, respectively. The starting point of this methodology is that policy is responsible and effective if it integrates formal and informal decision-making processes and decision implementation.
\end{abstract}

Key words: Backdoor politics, Development, Governance, Informality, Policy, Prebendalism.

\section{„ПОЛИТИКА У ЗАЛЕБУ“: ДОЗВОЉАВАЫЕ НЕФОРМАЛНОСТИ ЗА ФОРМАЛНИ РАЗВОЈ У АФРИЧКОЈ ДЕМОКРАТИЈИ}

\begin{abstract}
Апстракт
„Политика у залеђу” је израз који означава проучавање делотворне и одговорне јавне политике са аспекта неформалних политичких процеса. Студија проучава неформалне инпут детерминанте које утичу на одговорне јавне политике. Методолошки гледано, у раду су коришћени подаци Афробарометра, који процењује три земље западне, источне и јужне Африке - Кенију, Нигерију, Јужну Африку. Основно полазиште овог истраживања јесте да су политике одговорне и делотворне ако интегришу формалне и неформалне процесе одлучивања и спровођења одлука.
\end{abstract}

Кључне речи: „политика у залеђу”, развој, управљање, неформалност, политика, предбендализам. 


\section{INTRODUCTION}

All over the world, government operations are centred on the capability, effectiveness, responsiveness and efficiency of the people that constitutes it. Government cannot work effectively without human involvement in the administrative and technical decision making processes. However, humans as rational beings, are subjected to dynamic behaviour over time. Humans are subject to changes in behaviour as conditions change (Ghimire, 2018, p. 32). In decision and general policy making and analysis, it is not so easy to separate human personal egos and values from administrative due processes. In most decision making by government, there are elements of prejudice of the policy makers presumptuously coated in the will and interest of the general public - formally to ensure the greatest happiness of the greatest number of the people but informally for personal aggrandizements.

The Informalities are the other options such as shortcuts that make things such as regular policy making, analysis and implementation work faster in government and administration apart from the formal ways of regular administrative bureaucracy and rigmarole (Fox, 2018, p.16). The regular administrative bureaucracies in most cases are longer in procedure and tedious in implementation, but thorough enough to give the institution credibility and accountability. Government policies of either foreign policies or domestic policies usually take longer to be fulfilled whenever the normal due procedures are to be upheld strictly (Thrift, 2008, p. 13; Aluko 2015, p. 34). These long processes and administrative procedures are in most cases injurious to intergovernmental relations and actions that require prompt response and quick actions (Trautman 2016, p. 11; Aremu, Isiaq \& Aluko 2016, p. 24). This might further lead to administrative loss of focus and delay in the process of meeting up with the target of the achievement under focuse. If more of the quick administrative actions are jeopardised by administrative oligarchy and bureaucratic rigmarole it might result in government shut down in the long run. Informal administrative procedures mostly result in checkmate to the impeding loss in the country at large.

These informalities of short circuiting long processes so as to obtain the same desired end that the long circuit might produce are termed backdoor politics in this study. Cannonand Ali, $(2018$, p. 2) noted that backdoor politics are measures through which policies are initiated, analysed and implemented in most countries of the world through the influence of other options other than the formal means. This is informalities in formalities. Backdoor politics is a common phenomenon among political, social and economic administrators around the world. This informal procedural politics does facilitate the normal procedures in the administrative processes so as to achieve a quick result at a record time. Although backdoor politics is informal and to some extent contrary or antithetical to 
the norms and regular documentation of procedures of service, Finkeldey, (2018, p. 12) notwithstanding opined that it has brought professionalism on the formalities by it timely accomplishing the policy action implementation in public administration and governance.

These informalities (backdoor) permitted in the formalities are rampant because humans are social beings who are rational in the ways in which they obtain outcome of policy decisions. Communities around the world devise ways, the simplest and easiest ways to govern themselves so as to ensure their survival and provision of their immediate needs, as well as the needs ofthe future generations (Paiano 2008, p. 22; Tadros 2015, p. 12; Müller 2015, p. 35). Backdoor politics are no doubt present in all countries and even in the most formal procedures in both the public and private establishments. The levels of the backdoor politics may vary from one country to the other. The manner of these informalities manifesting may also vary depending on the level of the development of the country (Mustafic, 2017, p. 13). It should not be surprising to find that the level of development in a country corresponds to the volume of the informalities within formalities, short circuiting of long bureaucratic procedures and general backdoor politicking in getting formal governmental polices implemented other than the long and tedious bureaucratic rigmaroles. This implies that for governance to be responsive and prompt in action, the rate of informality approaches in the national policy making, implementing and feedbacks would be high and it would strategically be integrated into the formal policy cycle of the country.

The objective of this paper is to assess the extent to which backdoor politics exist, how it operates and propels development in Africa. Africa is selected to represent the developing democracies in the world. It is noteworthy to trace out and analyse the different levels of backdoor politicking which are identified as the informalities that emanate from both the domestic and the foreign realities. The study covers the following sections; conceptualising backdoor politics, theoretical framework using prebendal theory, the backdoor politics approach in developing countries, research methodology, presentation of data, and analysis of finding, conclusion and recommendation.

\section{CONCEPTUALISING BACKDOOR POLITICS}

Politics is multifaceted in its outlook. The term politics, according to David Easton, is the authoritative allocation of scarce values among a group of people. According to Nicollo Machiavelli, politics is any act in which the end justifies the means. Also, politics according to Harold Lasswell is about who gets what, when and how. Therefore, the act of getting things done without the stringent legal or fully documented procedures seems to be permitted for the progress of the state or the organization, and such a 
phenomenon is termed backdoor politics. Sizwe opined that it is the act of making a monotonous procedure simpler ('backdooring' procedures) so as to get quick results in governance $(2018$, p. 12). The backdoor phenomenon is regular and active in all polities - where events are supposed to be routed through a bureaucratic channel, but diverted to a fast lane due to the urgency and the level of influence mounted by some group of people to facilitate the processes (Muga, 2017, p. 32). Backdoor procedures are only virtual or quasi procedures, but not the actual procedures with the documented legal modus operandi in an organised setting (Zankina, 2017, p. 2). However, Aluko (2016a, p. 12) and Waikenda (2017, p. 2) opined that the regular outcome in backdoor politics is usually the same with the outcome of the actual procedures (the due process).

In fact, backdoor procedures are usually faster than the bureaucratic legal procedure in the organised settings such as government establishments and other private firms which make use of long and often cumbersome administrative procedures (Falkner, Hartlapp, Leiber \& Treib, 2002, p. 33). The politics of 'who gets what, when and how' is conditioned by who you know, where, when and how. This politics, to a great extent, conditions the procedures in public or private firms. Its adverse effects, if it is not properly managed, will results in favouritism, men-pleaser services, nepotism, bribery and other forms of corruption in the long run. This might imply a non-professional act by the administrators, but it simply confirms that the end justifies the means and all men have various levels of influence in society (Aluko, 2017, p. 2; Zankina, 2017, p. 2).

The non-equivocal availability and accessibility of men to some extent beyond the limit of proportionality gives room for informalities among the comity of friends and states in the wider view. Muga noted that informalities avert the formal approach and gets things done in a more relax atmosphere where the procedures are under fetters $(2017$, p. 4). This backdoor approach in politics often starts from the influence of the kitchen cabinet of the decision maker which comprises of the wife and immediate family members to his inner caucus of friends (business or administrative friends), and results in the pressure from government top political officials either within the state or outside.

The informalities in the formality depict backdoor politics processes of every policy formulated from its initiation to its implementation and feedback stage in the government which are short circuited by passing through an abridge process instead of the normal policy cycle. These informalities are seen as norms for the progress of a business or a country, and for the greatest happiness of the greatest number of people in the country at large. These informalities in official procedures, simply called backdoor politics in this study, encourage more effective and rapid outputs in the governmental bureaucratic procedures by creating a quasi-official route for the administrative processes and procedures. 


\section{THEORETICAL FRAMEWORK}

\section{Prebendal Theory}

Prebendalism refers to the act of getting things done in an informal approach. This approach may be legal with due processes outlined and followed, or illegal without the full adherence to the procedures of the due process. The theory is credited to Joseph Richard (1996). The theory depicts short circuiting the politics of policy formulation in governance and administration so as to get a desirable end within a short time. On the other hand, it is where cronies or members of an ethnic group are compensated whenever an individual from the group acquires political power. It is also where a public office or policy is used to hasten or shorten a political due process as a means to achieve a desired goal. This act is termed as prebendal act. In some cases, the prebends appropriated by the office holder are used to generate material benefits for themselves, their constituents and kin groups (Joseph, 1996, p. 2).

Prebendalism explains how the nature of politics and the role of the ruling elites contribute to the means of governance and development. It also explains the problem of state centred corruption in many developed and developing countries (Ogundiya, 2009, p. 12). Prebendalism is the phenomenon whereby public offices are regarded as the opportunity to make impact in the development of the state in a short period of time. This entails the partial or total suspension of the due process in the policy formulation, implementation and impact assessment. It may also affect the accountability of the political system.

In extreme cases, Wilson and Magam opined that the prebendal nature of backdoor politics is fundamental to the problem of political corruption $(2018$, p. 6). The impact might bring prompt or rapid short-term development, but with little accountability (Nye, 1967, p. 2). Prebendal politics in governance and administrative process does not mean that there will be no accountability in the process of governance and administration, but the extent of its operation might be low. However, it has the potential of speedy executive approval of public policy or project and its implementation or prompt completion to the benefit of the greatest number of the population.

The mechanism of operation of prebendalism in backdoor politics does not affect the critical democratic values, such as respect for the fundamental human rights of citizens, the constitution and rule of law, institutional autonomy and accountability. It does not affect the freedom, credible and competitive elections, strong and vibrant civil society and opposition political parties. It may subvert some of the principles by government initiating an expediting action so as to salvage a major political or socioeconomic damage or challenge. Backdoor politics help the government to prebend an action which should have taken a longer natural 
course to become shorter and faster so as to assist the government to meet up the time lag and the specific developmental targets.

Prebendalism, as a negative trend, deepens the connection between corruption and class formation (Bond, 2009, p. 22). The relationship between prebendal politics, the role of the ruling elites in widespread corruption and the damaging effects on development, democratic values and processes in the any country may be widened if accountability is totally suspended in the governance and the administrative operations. In such cases, there will be a high rate of allegations against political leaders on issues such as bribery, nepotism, cronyism and award of spurious contracts, inflation of contract sums, embezzlement and misappropriation of public funds, electoral fraud and abuse of office (Nye, 1967, p. 2). The continuity of this negative trend and practice has a high tendency of resulting into an increase in poverty levels, inequality, unemployment, -security issues, political instability, and infrastructural decay.

The phenomenon of prebendal politics, which corroborates backdoor politics, truly manifests in developing democracies due to the high rate of developmental lag or the developmental debt accumulated over time (Omodia \& Aliu, 2013, p. 10). Moreover, in the developed democracies, such acts exist at lower ebb which is more controllable by institutional mechanisms unlike the developing democracies that may lack strong institutions to curtail the excesses of backdoor politic and prebendal activities (Bond, 2009, p. 2).

Whenever prebendal activities of the government positively influence the political and socioeconomic development in the country, there will be prompt government actions that will hasten development and the distribution of the economic resources to all and sundry without any major bureaucratic rigmaroles and the concentration on cronies as the sole beneficiaries (Hornberger, 2018, p. 3). Equally, political appointments, contracts, promotions, jobs, cash transfer, and other state resources will be deployed to sustain the network of political and economic relationship, maintain political support and patronage, promote shared prosperity and enhance growth and development of both rural and urban centres (Joseph, 1996, p. 2; Omodia \& Aliu, 2013, p. 13).

\section{Backdoor Politics Approach in developing Countries}

The backdoor politics approaches and patterns of occurrence in the developing economies are numerous. This will be discussed in the four facets of their operations and influences. These include: the political approach, the economic approach, the ethnic approach and the religious approach. The political approach to backdoor politics in the developing countries involves the government officials' involvement in the politicking by bypassing government bureaucratic procedures. The recruitments of staffs are done from the informal procedure from the corridor of political 
power, influence and authority instead of merit, and formal bureaucratic procedures legally backed by the state law.

The recruitments done through informal-backdoor politics will always give room for more compromise in favour of the person that gave them the job offer or opportunity informally, which, in this case, is the political office holder. Whenever the political office holder need to pass through the legal rational bureaucratic procedure of the office, his beneficiaries and cronies will backdoor the process so as to get his requests with rapt attention and without much stress (Westra, 2014, p. 12; Bachmann, 2016, p. 2). Hope opined that if this is not well curtailed with regular accountability, it will exert some negative effects on the day to day running of the office and the entire democratic development of the state at large (2018, p. 11).

The economic approach to backdoor politics in the developing countries involves the illegal flow of financial largess within the government to buy off official protocols out of the way for the informal processes (Aluko, 2017, p. 7; Hope, 2018, p. 11). This, in most cases, is referred to as bribery and misappropriation of funds. Hornberger'sanalysis concluded that the financial largess might not be to bend the procedure of operations in the state, but to compensate the officers on duty for the fast tracking and unofficially handling of the official procedures. In other words, the issue of quid pro quo is a form of backdoor politics of the economic approach (Duster, 2004, p. 6; Aluko, 2016b, p. 12). It implies that you give something to get something in return.

Realists and moralists see this as antithetical to development and sustainability of official state procedures, but the idealist and the amoral sees it as a means to an end which might benefit the whole state in the long run (Gounev, 2011, p. 2). Economic approaches revealed that money politics represent a way in which a government official may be tipped away from his official duty so as to boycott certain long procedures in favour of the person who needs to get the advantage. If the event is for the public good, the process short circuiting it financially would propel the early manifestation of the good. However, this must be monitored so as to obtain the prompt delivery of the good.

The ethnic approach to backdoor politics in the developing countries centres on the interest of an ethnic group at the expense of the others. Miller remarked that the quest for prosperity of social groups propels backdoor approaches to political power $(2018$, p. 3). Therefore, the ethnic approach to backdoor politics in the developing economies involves the giving of sentimental prejudice to issues or policies that torch the policy maker's close relative, family and personal life. This, therefore, allows more soft torches to be given to such issues or policies while other policiesreceive the total official attention without any iota of informalities. 
The backdoor politics of favouritism and ethnic affinity prejudice centres on a given group of people, more public goods in their geographical location in terms of public projects contracting and execution, and the softening of the bureaucratic process to aid an ethnic affinity, or in favour of one ethnic group rather than another. Ho and Chua posited that this approach usually promotes divisions, personal prejudice, egocentrism, nepotism and sentimental prowess across $(2015, \mathrm{p}$. 2). If it is not properly handled, it could lead to social mishaps such as ethnic dominance, ethnic superiority riots and violence.

This religious approach has a link with the ethnic approach to backdoor politics in the developing countries. This involves the showing of more favour to a particular religious group while others are neglected. It also involves the neglect of most or few public procedures or due process due to the religious affinity of the benefactors. This issue, in most cases, if not properly handled, leads to religious bigotry and chauvinism. The positive effect is that it reduces the poverty level in the country because the beneficial religious group might be from various ethnic groups (USAID, 2006). Therefore, rapid development will circulate the country and more people that are affiliated with the religious group will also enjoy state informalities.

All of these approaches to backdoor politics in the developing countries have some element of progress and development inference on the governmental achievements. In some cases it has led to the criticism of the government. Excessive bureaucratic procedures slow down governmental actions especially when urgent questions need answering and pressing problems require solutions. The level of informalities therefore in the formal procedures, if duly utilized, will enhance progress in the country if accountability is not totally negotiated in the process. The manifestations of the approaches should as well be censored so as to get a rapid and popular response from the general populace when it is going badly.

\section{METHODOLOGY}

The research objective of this study is to assess the extent to which backdoor politics exist, how it operates and propels development in Africa. The Afrobarometer time series online data presentshow different groups and government officials influence politics and governance through informalities and backdoor politics in three countries in Africa. The countries are randomly selected from east, west and southern Africa respectively. These countries are: Kenya, Nigeria and South Africa respectively. Descriptive analyses with the use of simple percentage and bar charts are employed.

Some indicators of the presence of backdoor politics are selected to measure the extent to which informalities and backdoor politics operations affect policies and propel development in Africa. Such indicators include; ethnic group's political influence on the government policies, how often officials go unpunished or accountability, the extent of the traditional 
leaders' influence on the governing of local community, the influence of civic organizations and non-governmental organizations (NGO) on policies and development, the influence of international businesses and investors on getting things done through the backdoor rather than the formal procedures in the government.

\section{THE PRESENTATION OF DATA AND THE ANALYSIS}

This section of the paper presents data on the reality of backdoor politics' informal influence on the country and the policy makers in Africa by state and non-state actors. Descriptive analyses with the use of bar charts are employed. The following actors' influences are considered; ethnic groups, government officials, traditional rulers, civic organizations, international business investors and international donor and nongovernmental organization (NGO) are taken into consideration in this study.

Table 1. Ethnic group's political influence

\begin{tabular}{lccc}
\hline & Kenya & Nigeria & South Africa \\
\cline { 2 - 4 } Ethnic group's political influence & R4 2008/2009 & R4 2008/2009 & R4 2008/2009 \\
\hline Much more & 8 & 11 & 6 \\
More & 16 & 19 & 10 \\
Same & 36 & 38 & 41 \\
Less & 25 & 22 & 13 \\
Much less & 13 & 6 & 7 \\
\hline
\end{tabular}

Source: Afrobarometer (2017) www.afrobarometer.org

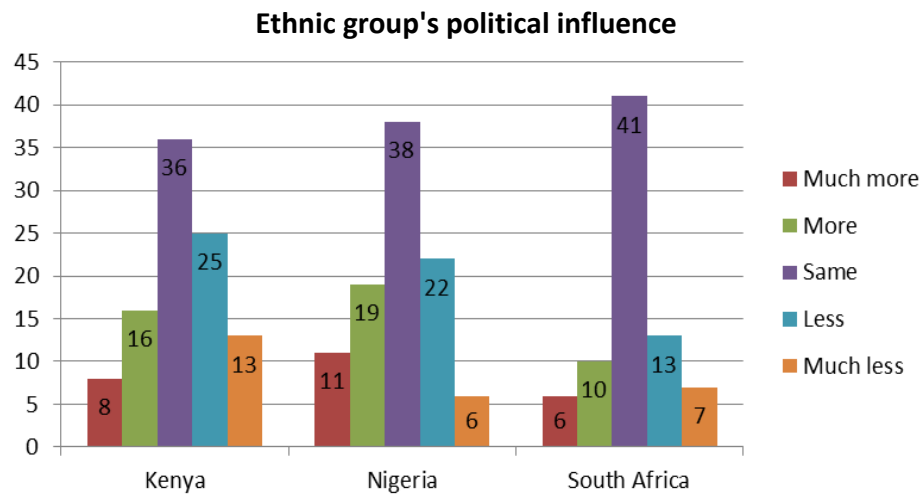

Figure 1. Ethnic group's political influence

Table 1 and Figure 2 above present data on ethnic groups' political influence on the country in Africa. The data presented comparatively considered three countries in Africa which include Kenya, Nigeria and South Africa, which are randomly selected for the study in Africa. 
Table 2. How often officials unpunished

\begin{tabular}{|c|c|c|c|}
\hline \multirow{2}{*}{ How often officials unpunished } & Kenya & Nigeria & South Africa \\
\hline & R6 2013/2014 & R6 2013/2014 & R5 2011/2012 \\
\hline Never & 7 & 11 & 19 \\
\hline Rarely & 13 & 19 & 23 \\
\hline Often & 37 & 33 & 38 \\
\hline Always & 39 & 35 & 18 \\
\hline Don't know & 4 & 2 & 2 \\
\hline
\end{tabular}

Source: Afrobarometer (2017)

How often officials unpunished

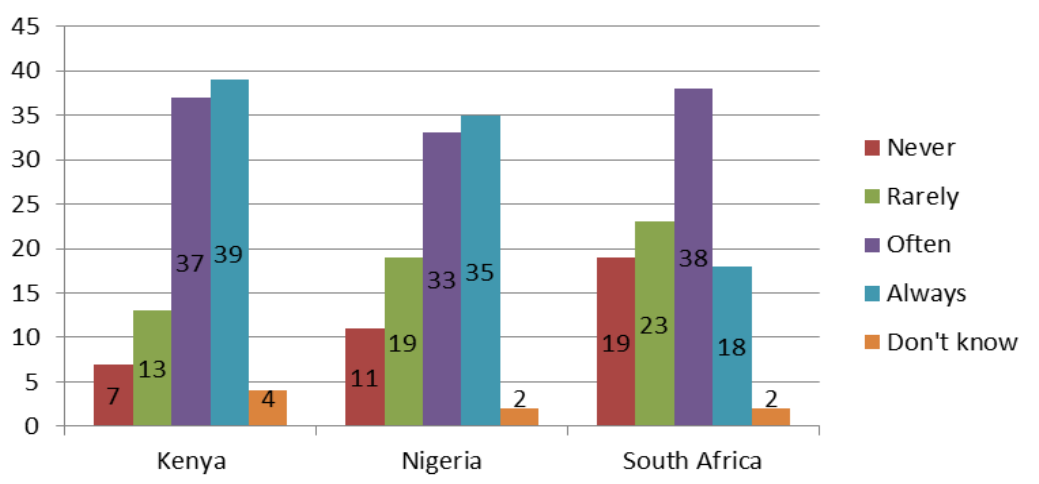

Figure 2. How often officials unpunished

Table 2 and Figure II 2 above present data on how often officials of the state go unpunished due to their backdoor politics and influence on the policy and decision makers.

The data presented comparatively considered three countries in Africa which include Kenya, Nigeria and South Africa, which are randomly selected for the study in Africa.

Table 3. Traditional leaders influence governing local community

\begin{tabular}{llcc}
\hline $\begin{array}{l}\text { Traditional leaders influence governing } \\
\text { local community }\end{array}$ & Kenya & Nigeria & South Africa \\
\hline None & 12.9 & 8.8 & 25.9 \\
A small amount & 30.6 & 30.8 & 22.1 \\
Some & 28 & 31.3 & 22.2 \\
A great deal & 18.1 & 19 & 9.8 \\
Don't know & 10.4 & 10.1 & 20 \\
\hline
\end{tabular}

Source: Afrobarometer (2017) 


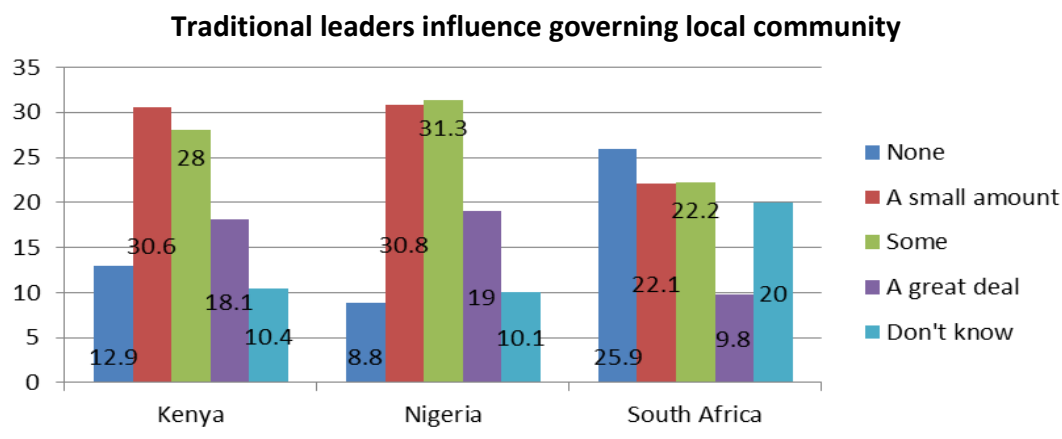

Figure 3. Traditional leaders influence governing local community

Table 3 and Figure 3 above present data on traditional leaders' influence in governing the local community policy and the decision making process. It is important to note that the local jcommunity is either rural or urban, which the traditional leaders control within the ambient of the state law. The data presented comparatively considered three countries in Africa which include Kenya, Nigeria and South Africa, which are randomly selected for the study in Africa.

Table 4. Influence of civic organizations and NGOs

\begin{tabular}{lccc}
\hline Influence of civic organizations & Kenya & Nigeria & South Africa \\
\cline { 2 - 4 } and NGOs & R4 2008/2009 & R4 2008/2009 & R4 2008/2009 \\
\hline Far too little & 8 & 10 & 13 \\
Somewhat too little & 16 & 20 & 16 \\
About the right amount & 26 & 24 & 20 \\
Somewhat too much & 14 & 12 & 13 \\
Far too much & 8 & 3 & 7 \\
Don't know & 26 & 32 & 31 \\
\hline
\end{tabular}

Source: Afrobarometer (2017)

\section{Influence of civic organizations and NGOs}

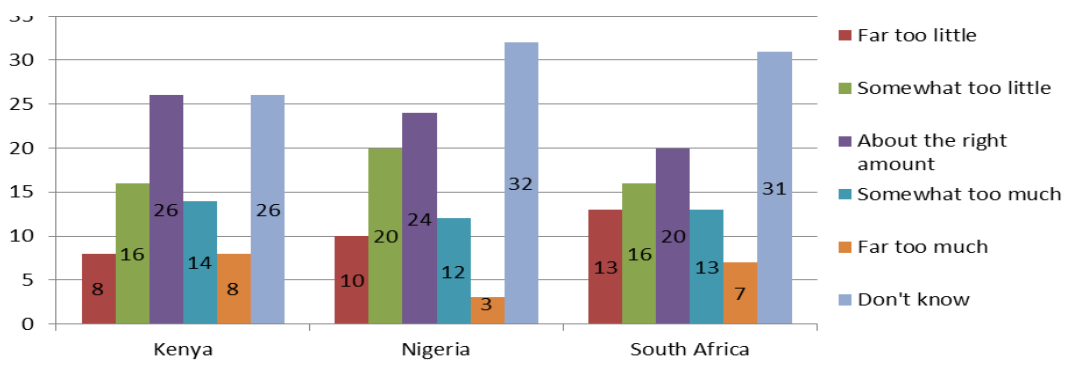

Figure 4. Influence of civic organizations and NGOs 
Table 4 and Figure 4 above present data on the influence of civic organizations and nongovernmental organizations (NGOs) on policy and the decision making process in the country. The data presented comparatively considered three countries in Africa, which include Kenya, Nigeria and South Africa which are randomly selected for the study in Africa.

Table 5. Influence of international businesses and investors

\begin{tabular}{lccc}
\hline Influence of international & Kenya & Nigeria & South Africa \\
\cline { 2 - 4 } businesses and investors & R4 2008/2009 & R4 2008/2009 & R4 2008/2009 \\
\hline Far too little & 17 & 8 & 12 \\
Somewhat too little & 25 & 21 & 15 \\
About the right amount & 13 & 23 & 23 \\
Somewhat too much & 6 & 4 & 13 \\
Far too much & 1 & 32 & 7 \\
Don't know & Source: Afrobarometer (2017)
\end{tabular}

\section{Influence of international businesses and} investors

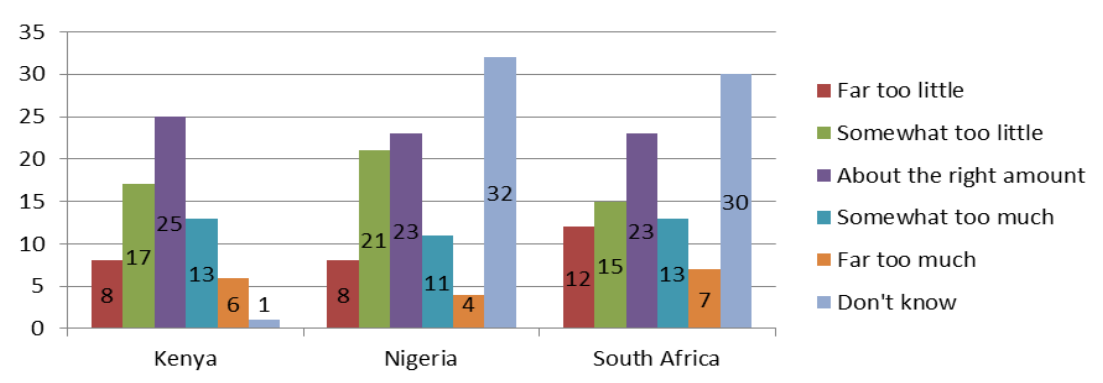

Figure 5. Influence of international businesses and investors

Table 5 and Figure 5 above present data on the influence of international businesses and investors on policy and the decision making process in the country. The data presented comparatively considered three countries in Africa which include Kenya, Nigeria and South Africa, which are randomly selected for the study in Africa.

\section{ANALYSIS OF FINDINGS}

From Table 1 and Figure 2 above, about twenty four percent (24\%) of Kenyans believe that ethnic groups have significant political influence on the country (a combination of much more and more). Thirtysix percent $(36 \%)$ of the populace opine that ethnic groups have the same level of 
influence on the country as do other state or non-state groups, while thirty eight percent $(38 \%)$ perceive that ethnic groups in Kenya have less significant political influence on the country (a combination of less and much less). This corroborates what Hanson (2008, p. 2) and Muga's (2017, p. 7) claim that the ethnic groups in Kenya have some level of significant impact on the policy makers on both formal and backdoor informal politics levels.

Similarly to Kenya, about thirty percent (30\%) of Nigerians believe that ethnic groups have a significant political influence on the country (a combination of much more and more). Thirty eight percent (38\%) of the populace opines that ethnic groups have the same level of influence on the country as the other state or non-state groups, while twenty eight percent (28\%) perceive that ethnic groups in Nigeria have less significant political influence on the country (a combination of less and much less). With regard to this, Okeke claims that the ethnic groups in Nigeria have a significant level of impact on the policy makers on both formal and the backdoor politics informal levels (2017, p. 5).

Unlike Nigeria, in the Republic of South Africa, about sixteen percent $(16 \%)$ of South Africans believe that ethnic groups have a significant political influence on the country (a combination of much more and more). Forty one percent (41\%) of the populace opines that ethnic groups have the same level of influence on the country as the other state or non-state groups, while twenty percent (20\%) perceive that ethnic groups in Nigeria have a less significant political influence on the country (a combination of less and much less). This implies that the ethnic groups in South Africa have a less significant level of impact on the policy makers on both formal and backdoor politics informal levels (Hunter, 2007, p. 14). Bond on the other hand, argues that some ethnic groups in certain parts of the country have more influence on politics than the other $(2009$, p. 2).

From Table 2 and Figure 2 above, about seven percent (7\%) of Kenyans opine that officials of the state never go unpunished regardless of their status, while thirteen percent $(13 \%)$ perceive that they rarely go unpunished. However, thirty seven percent $(37 \%)$ and thirty nine percent (39\%), which is a significant percentage, perceive that officials of the state often and always go unpunished, respectively. These findings support what Waikenda (2017, p. 5) and Hope (2018, p. 7) deduced, that the political officials in Kenya have a high level of significant impact on the policy makers on both the formal level and the backdoor politics, informal order, and that they often go unpunished.

Similarly to the backdoor influence of public officials in Kenya, Table II and Figure II above reveal that about eleven percent (11\%) of Nigerians think that officials of the state never go unpunished regardless of their status while nineteen percent $(19 \%)$ perceive that they rarely go unpunished. However, thirty three percent (33\%) and thirty five percent 
(35\%),which is a significant percentage, perceive that officials of the state often and always go unpunished, respectively. This implies that the findings of Ejimabo (2013, p. 6), that the public officials in Nigeria have significant impact on the policy makers using the informal order of backdoor politics, is sacrosanct.

From Table 2 and Figure 2 above, the influence of public officials in South Africa is significant. About nineteen percent (19\%) of South Africans think that officials of the state never go unpunished regardless of their status, while twenty three percent $(23 \%)$ perceive that they rarely go unpunished. However, thirty eight percent (38\%) and eighteen percent (18\%), which is a less significant percentage, perceive that officials of the state often and always go unpunished, respectively. This justifies Oldfield and Greyling's (2015, p. 6) claim that the officials of the state in South Africa a have high level of significant impact of backdoor politics influence on the policy makers. This, in their opinion, hastens development in the governance process.

From Table 3 and Figure 3 above, about thirteen percent (13\%) of Kenyans perceive that the traditional leaders have no influence in the local community policy, governance, development and the decision making processes. About thirty one percent (31\%), however, think that they have a small amount of influence of both formal and informal approaches in the governing of the local community policy and the decision making processes. Also, forty six percent (46\%) display a combination of attitudes reflecting a perception that the traditional leaders have significant influence in the governing of the local community policy and the decision making processes. This finding is generally supported in the literature which upholds that the traditional leaders have a significant level of influence on the country from both the formal and the informal (backdoor politics) levels in Kenya (Makora, 2012, p. 4; Michira, 2018, p. 12).

However, similarly to the data about Kenya, a less significant percentage, about eight percent $(8 \%)$, of Nigerians perceive that the traditional leaders have no influence in governing the local community policy and the decision making processes. About thirty one percent (31\%) think that they have little influence on both the formal and informal (backdoor politics) forms in governing the local community policy and the decision making processes. Also, twenty nine percent (29\%) of the people claim that the traditional leaders have a very significant level of influence in the policy making, governance and development of the local community and general decision making processes. This corroborates Ejimabo's (2013, p. 21) opinion that the traditional leaders have a significant level of impact on the country by utilising both the formal and the informal (backdoor politics) channels of governance and decision making in Nigeria.

Unlike Kenya and Nigeria, about twenty six percent (26\%) of South Africans perceive that the traditional leaders have no influence in 
governing the local community policy and the decision making processes. About twenty two percent (22\%) however think that they have a small amount of influence on both the formal and informal (backdoor politics) channels in the governance and the decision making processes of the local community. Also, thirty two percent $(32 \%)$ remarked that the traditional leaders have a very significant level of influence in the governing and the decision making processes in the local community. This substantiates the opinions of Hunter (2007, p. 12) and Sizwe (2018, p. 13) that the traditional leaders have a minimal level of impact on the country from both the formal and the informal (backdoor politics) levels in South Africa.

Table 4 and Figure 4 abovereveal that about twenty four percent (24\%) of Kenyans noted that the level of influence of civic organizations and nongovernmental organizations (NGOs) on policy and the decision making process in the country is fairly insignificant (a combination of far too little and somewhat too little). However, another twenty six percent (26\%) perceived that they have a fair level of influence on the country utilising both formal and the informal approaches. About twenty two percent (22\%) show attitude of a combination of 'somewhat too much' and 'far too much', and think that the level of influence of civic organizations and nongovernmental organizations (NGOs) on policy and the decision making process in the country is very significant. Considering the level of fairly and strongly significant, it is important to remark that this justifies Hope's view (2018. P. 14) that the impact of the civic organizations and nongovernmental organizations (NGOs) on policy and the decision making process in the Kenya is very significant.

In Nigeria however, Table 4 and Figure 4 above show that about thirty percent (30\%) opine that the level of influence of civic organizations and nongovernmental organizations (NGOs) on policy and the decision making process in the country is minimal (a combination of 'far too little' and 'somewhat too little'). However, another twenty four percent (24\%) perceive that they have fairly significant influence on the country using both formal and the informal mediums. Also about fifteen percent (15\%) show attitude that is a combination of 'somewhat too much' and 'far too much' claiming that the level of influence of civic organizations and nongovernmental organizations (NGOs) on policy and the decision making process in the country is very significant. Ejimabo (2013, p. 11) supports the claim that the impact of the civic organizations and nongovernmental organizations (NGOs) on policy and the decision making process in Nigeria is very significant.

Table 4 and Figure 4 above show that in South Africa, about twenty nine percent (29\%) think that the level of influence of civic organizations and nongovernmental organizations (NGOs) on policy and the decision making process in the country is too little (a combination of 'far too little' and 'somewhat too little'). However, another twenty percent (20\%) perceived it 
as a fairly significant influence on the country. Also about twenty percent (20\%) see it as a combination of 'somewhat too much' and 'far too much' therefore claiming that the level of influence of civic organizations and nongovernmental organizations (NGOs) on policy and the decision making process in the country is very significant. Considering Edwards (2014, p. 9) and Sizwe's (2018, p. 14) remarks on the informalities in civic organizations and nongovernmental organizations (NGOs) on policy and the decision making processes and operations, it is important to emphasize that the impact of the civic organizations and nongovernmental organizations (NGOs) on policy and the decision making process in the South Africa is very significant.

From Table 5 and Figure 5 above, it is observed that about twenty five percent $(25 \%)$ of Kenyans think that the (formal and informal) influences of international businesses and investors on policy and the decision making process in the country is insignificant (a combination of 'far too little' and 'somewhat too little'). However, about twenty five percent $(25 \%)$ also perceive that the international businesses and investors have a less significant influence on the policy and the decision making process in the country. Also about nineteen percent (19\%) of the populace (a combination of 'somewhat too much' and 'far too much') are of the opinion that the influence of international businesses and investors on policy and the decision making process in the country, either through the formal means or the informal backdoor politics, is very significant. Miller (2018, p. 12) supports the position that prosperity in Kenya is not evenly circulated due to the reduced influence of international businesses and investors on policy and the decision making process in the country.

In Nigeria, much like in Kenya, Table 5 and Figure 5 above reveal that about twenty nine percent (29\%) of Nigerians think that the influence of international businesses and investors on policy and the decision making process in the country is not significant (a combination of 'far too little' and 'somewhat too little'). However, about twenty three percent (23\%) also perceive that the international businesses and investors' influence on the policy and the decision making process in the country is fairly significant. Also about nineteen percent (19\%) of the populace (a combination of 'somewhat too much' and 'far too much') are of the opinion that the influence of international businesses and investors on policy and the decision making process in the country, either through the formal means or the informal backdoor politics, is very significant. Okeke (2017, p. 13) remarks that the level of development in Nigeria is slow due to the low influences exhibited by international businesses and investors on policy and the decision making process in the country.

Table 5 and Figure 5 above reveal that the perceived phenomenon in South Africa is similar to those in Nigeria and Kenya. About twenty nine percent $(27 \%)$ of South Africans think that the influence of international 
businesses and investors on policy and the decision making process in the country is too insignificant (a combination of 'far too little' and 'somewhat too little'). However, about twenty three percent (23\%) also perceive that the international businesses and investors have about the right amount of influence on the policy and the decision making process in the country. Also, about twenty percent $(20 \%)$ of the populace (a combination of 'somewhat too much' and 'far too much') are of the opinion that the influence of international businesses and investors on policy and the decision making process in the country, either through the formal means or the informal backdoor politics, is very significant. This substantiates Oldfield and Greyling's assertion (2015, p. 8) that informalities of international businesses and investors have little effect on the entire country.

\section{CONCLUSION AND RECOMMENDATION}

Backdoor politics have affected policies and development in Africa in both positive and negative ways. This study analyzes the reality of informalities in the day to day government bureaucratic procedures. The comparative analyses of three African states employs the use of descriptive analyses and the simple percentage presented in tables and bar charts. The mentioned African states include Kenya, Nigeria and South Africa. The analysis reveals that informalities and backdoor politics exist in government and policy making processes in Africa. The level of impact of informalities and backdoor politics in these African country is very high and has significant impact.

It is important to note that the social group leaders, private sector and government officials, embark on backdoor approach in getting things done in the government circuit. However, their level of influence varies from country to country. The rationale behind the informal approach to government is to enhance quick development, prevent delays and other long administrative rigmarole. Wherever there is human interaction, especially in developing democracies there are the tendencies that the personal handling of the affairs, even public affairs, might permit some informality in the formal administrative bureaucratic procedures due to certain exigencies or personal idiosyncrasies.

The analysis of backdoor politics reveals that there are four basic perspectives or approaches through which informality operates or creeps into the political system. These approaches include the political approach, the economic approach, the ethnic approach and the religious approach. Backdoor politics might prevent adequate accountability, but it could also enhance rapid response to germane issues in the country if judiciously employed. No doubt, due process is the best mode of operation in governance and administrative procedures, but with that, there is the risk that the due process might be short-circuited for a prompt response and the public needs to be achieved. 
The major setback to the prowess of backdoor politics is when it goes to the extreme, as prebendal theory explains it. The traits of corruption and egocentric political drives will begin to manifest. The wealth of the country at this moment will be circumvent by a few people and there will be a wide spread of poverty and uneven development in the country. Therefore, it is important to be able to determine the situations in which personal prejudice is introduced or lobbied into a public project so as to be able to monitor it against excesses. On the short run, backdoor politics is profitable for good governance and accelerated development if the extent of accountability in the process is high.

Permitting backdoor politics and informalities in formal governance aids governance speed and closeness of public largess and goods to the general public. Formalities breeds+ time wasting, corruption, bribery and delay in execution of urgent projects. Government officials must be aware that speeding up a due process is a form of backdoor politics which can aid administrative responsiveness to the demand of the people, effectiveness in policy execution and the personnel output level will become more efficient. Therefore, due process can be maintained side by side with backdoor politics but with a high level of accountability.

It is of noteworthy to recommend that permitting the normal course of actions or due process to take its course when issues are linked to the common man, and this is inevitable in governmental and nongovernmental sectors of the state. However, the extent of permitting interference or backdoor politics in the policy and decision making process of the government must be censored in the light of public opinion and accountability. The government in a democratic setting should endeavour to allow the input of the greatest number of the people before a policy should be implemented, despite the possible urgency. This popular opinion will neutralise the negative effects of backdoor politics in the state. Nevertheless, boundaries should be drawn between a potentially egocentric and statecentric agendas so as to prevent political sabotage, prejudice and corruption in the country.

\section{REFERENCES}

Afrobarometer (2017) Africa Political, Social and Economic Assessments-Time Series Data www.afrobarometer.org

Aluko O. I., (2015). Political Economy of Crony Capitalism: The Prospect and the Bane Journal of Economics Library Volume 2 Issue 3

Aluko O. I. (2016a) Refocusing The Focus, Metafocus And Profocus: Mopping Urban Violence In Developing Cities. Journal of Social Science Vol 5 Issue 2

Aluko O. I. (2016b) Urban Violence and Demographic Delimitations in Democratic Governance Journal of Siberian Federal University Humanities \& Social Sciences 1 (9) 235-250

Aluko O. I. (2017) Political Economy of Crony Inequality Among Nations: A Study on Capitalism and Socialism Journal of Community Development Research 
(Humanities and Social Sciences) Naresuan University, Taphao Volume 10, No. 2.

Aremu F.A., Isiaq A. A. and Aluko O.I. (2016) Managing Democratic Structures in Africa. Ilorin Journal of Administration and Development (IJAD) Vol 2 No 1

Bachmann, G. (2016). Science for Sustainability-A Societal and Political Perspective. In Sustainability Science (pp. 359-367). Springer Netherlands.

Bond, P. (2009). Realistic postneoliberalism-a view from South Africa. Development Dialogue, 51(1), 193-211.

Cannon, B. J., \& Ali, J. H. (2018). Devolution in Kenya Four Years On: A Review of Implementation and Effects in Mandera County. African Conflict and Peacebuilding Review, 8(1), 1-28.

Duster, T. (2004). Backdoor to Eugenics. New York: Routledge.

Ejimabo N.O. (2013) Understanding the Impact of Leadership in Nigeria: Its Reality, Challenges, and Perspectives SAGE: 1-14 DOI: 10.1177/2158244013490704

Edwards I. (2014) A rainbow, prophets and the vortex: The state of South Africa, circa 2012-2013. S Afr J Sci Vol 110 No (3/4), http://dx.doi.org/10.1590/sajs. 2014/a0054

Falkner G., Hartlapp M., Leiber S. and Treib O. (2002). Opposition through the Backdoor? The Case of National Non-Compliance with EU Directives Institut für Höhere Studien (IHS), Wien Institute for Advanced Studies, Vienna Reihe Politikwissenschaft Political Science Series 83

Finkeldey, J. (2018). Unconventionally contentious: Frack Free South Africa's challenge to the oil and gas industry. The Extractive Industries and Society, 5(4), 461-468.

Fox, G. R. (2018). The 2017 Shooting of Kuki Gallmann and the Politics of Conservation in Northern Kenya. African Studies Review, 1-27.

Ghimire, S. (2018). The Politics of Peacebuilding: Emerging Actors and Security Sector Reform in Conflict-affected States. Routledge.

Gounev P.M. (2011). Backdoor traders: illicit entrepreneurs and legitimate markets. A thesis submitted to the Department of Sociology of the London School of Economics for the degree of Doctor of Philosophy, London, The London School of Economics and Political Science.

Hanson S. (2008) Understanding Kenya's Politics Council on Foreign Relations https://www.cfr.org/backgrounder/understanding-kenyas-politics

Ho, E. L. E., \& Chua, L. J. (2015). Law and 'race' in the citizenship spaces of Myanmar: spatial strategies and the political subjectivity of the Burmese Chinese. Ethnic and Racial Studies, 1-21.

Hope, K. R. (2018). The police corruption "crime problem" in Kenya. Security Journal, $1-17$.

Hornberger, J. (2018). A ritual of corruption: how young middle-class South Africans get their driver's licenses. Current Anthropology, 59(S18), S138-S148.

Hunter J. (2007) South Africa through The Back Door https://nacla.org/article/southafrica-through-back-door accessed on 17/8/2018

Joseph A. R (1996) Democracy and Prebendal Politics in Nigeria: the Rise and fall of the Second Republic, Cambridge: University Press

Makora W. (2012) How Kibaki Gave Uhuru Kenyatta Power Through the Backdoor Kenya Today https://www.kenya-today.com/opinion/uhuru-kenyatta-mwaikibaki-presidency

Michira M. (2018) Companies take best produce out of Kenya through backdoor https://www.standardmedia.co.ke/business/article/2001277901/how-foreigninvestors-rob-coffee-farmers-of-billions-in-profit

Miller, N. (2018). Kenya: The quest for prosperity. Routledge. 
Muga W. (2017) Titan of Coast backroom politics https://www.the-star.co.ke/news/2017/ 01/11/titan-of-coast-backroom-politics_c1485159

Müller, C. (2015). NGOs. A new history of transnational civil society. European Review of History: Revue européenne d'histoire, 1-3.

Mustafic C.L. (2017) Backdoor Politics Fantastic Fiction Publishing

Nye J. S. (1967) Corruption and Political Development: A Cost Benefit Analysis American Political Science Review. 61.

Ogundiya, I.S.. (2009) Political Corruption in Nigeria: Theoretical Perspectives and some Explanations, Anthropologist, 11(4): 281 - 292.

Okeke, R.C. (2017) Political Culture, Democracy and Development in Nigeria Journal of Politics and Law Vol, 2 (4): 1-9

Oldfield S. and Greyling S. (2015) Waiting for the state: a politics of housing in South Africa Environment and Planning vol 47 doi:10.1177/0308518X15592309

Omodia, S. and Aliu, M. (2013) Governance and Threats to National Security in Emerging Democracies: A Focus on the Nigerian Fourth Republic, Research on Humanities and Social Sciences, 3(4): 36 - 42.

Paiano M. (2008). Democratisation through the backdoor: Civilian Power Europe and the European Neighbourhood Policy. A Republican interpretation of political conditionality, University of Essex GARNET Working Paper No: 42/08

Sizwe P. (2018) Backdoor privatisation of SOEs will be fought - COSATU http://www.politicsweb.co.za/politics/backdoor-privatisation-of-soes-will-befought--cos accessed on 17/8/2018

Tadros, M. (2015). Beyond Tinkering with the System: Rethinking Gender, Power and Politics. IDS Bulletin, 46(4), 66-74.

Thrift, N. (2008). Non-representational theory: Space, politics, affect. Routledge.

Trautman, R. R. (2016). Small-Town Policy Makers. Public Administration Review, $76(2), 221-224$

USAID (2006) Democracy and governance assessment of Nigeria ARD, Inc. 159 Bank Street, Suite 300 Burlington, Vermont 05401 USA

Waikenda M. (2017) NASA seeks power via backdoor https://www.the-star.co.ke/ news/2017/09/26/nasa-seeks-power-via-backdoor_c1641163

Westra L. (2014) The supranational corporation: beyond the multinationals Chicago: Haymarket Books

Wilson, R., \& Magam, L. (2018). Frustration-Aggression, Afrophobia and the PsychoSocial Consequences of Corruption in South Africa. In The Political Economy of Xenophobia in Africa (pp. 93-107). Springer, Cham.

Zankina, E. (2017) Backdoor politics: politicisation through restructuring in the Bulgarian civil service, East European Politics, 33:2, 291-308, DOI: 10.1080/ 21599165.2016.1260550 


\title{
„ПОЛИТИКА У ЗАЛЕБУ“: ДОЗВОЉАВАЊЕ НЕФОРМАЛНОСТИ ЗА ФОРМАЛНИ РАЗВОЈ У АФРИЧКОЈ ДЕМОКРАТИЈИ
}

\author{
Aluko Opeyemi Idowu \\ Универзитет Илорин, Департман политичких наука, Нигерија
}

\section{Резиме}

Влада своје деловање усмерава на способност, ефикасност, одрживост и ефективност. Влада не може ефикасно одлучивати без укључивања људи приликом доношења одлука. Постоје предрасуде да доносиоци одлука полазе од воље и интереса шире јавности упркос чињеници да је формални циљ уважавање интереса и потреба што већег броја људи. Доношење одлука подразумева и неформалне процесе који се одређују као друга опција, као што су пречице које чине да се доношење одлука спроводи брже у администрацији и управи. Редовне процедуре су, у већини случајева, дуже и спорије и довољно утемељене на институционалним процедурама, које дају кредибилитет и одговорност.

„Политика у залеђу” је израз који означава проучавање делотворне и одговорне јавне политике са аспекта неформалних политичких процеса. Студија је усмерена на сагледавање питања како неформални процеси утичу на брзину доношење одлука у администрацији и управи. Методологија истраживања заснована је на подацима базе података „Афробарометра”, на основу којих се процењује у коликој мери „политика у залеђу” постоји, како делује и подстиче развој у три земље западне, источне и јужне Африке - Кеније, Нигерије, Јужне Африке. Истраживања су у раду показала да је утицај неформалних процеса и „политике у залеђу” на политику и развој демократије у анализираним земљама висок, што захтева одговарајуће реаговање. Предлаже се да утицај „политике у залеђу” у процесу доношења одлука мора бити контролисан и вођен јавним мишљењем и одговорношћу. Демократско окружење захтева од једне владе да процес доношења одлука буде у функцији што већег броја људи без обзира на њихову хитност и тражену брзину. На овај начин ће се неутрализовати негативни ефекти „политике у залеђу” у једној држави. 